\title{
Ostracods Late Devonian mass extinction: the Schmidt quarry parastratotype (Kellerwald, Germany)
}

\section{L'extinction en masse des Ostracodes du Dévonien supérieur : le parastratotype de la carrière Schmidt (Kellerwald, Allemagne)}

\author{
Jean-Georges CASIER ${ }^{1}$ and Francis LETHIERS ${ }^{2}$ \\ 1 Dépantement de paléontologie, Institut royal des Sciences naturelles de Belgique, 29, rue Vautier, 1000 Bruxelles, Belgique \\ ${ }^{2}$ Laboratoire de micropaléontologie, département de géologie sédimentaire, Université Paris 6, T25-15, 4E, case 104-4, 4, place Jussieu, 75252 Paris \\ cedex 05 , France
}

\begin{abstract}
Sixty-eight ostracod species have been recognized (the benthonic one for the first time) close to the Frasnian/Famennian boundary in the Schmidt quarry parastratotype. In the Late Frasnian, ostracods belong to an assemblage of the Eifelian ecolype and to the Myodocopid ecotype. In tlue base of the Famennian, they belong exclusively to the Eifelian ecotype.

The oxygen content of the bottom waters during the deposition of the Upper Kellwasser horizon was highly unstable whereas this horizon was known to be anoxic. The late Devonian mass extinction, probably the second in order of magnitude during the Phanerozoic, took place in the last $5 \mathrm{~cm}$ of the Upper Kellwasser horizon. Twelve ostracod species recognized in the Schmidt quarry survived this event.
\end{abstract}

Keywords: Ostracods, Frasnian/Famennian boundary, Kellerwald, Germany, Extinction

\section{RÉSUMÉ}

Soixante-buit espèces d'Ostracodes sont reconnues (les espèces benthiques pour la première fois) de part et d'autre de la limite Frasnien/Famennien dans le parastratotype de la carrière Schmidt. Le sommet du Frasnien contient des Ostracodes appartenant à un assemblage de l'écotype de l'Eifel et à l'écotype à Myodocopida, alors que, dans la base du Famennien, les Ostracodes appartiennent exclusivement à l'écotype de l'Eifel.

La teneur en oxygène dissous des eaux du fond a fortement varié au cours du dépôt du Kellwasser supérieur dans la carrière Scbmidt, alors que ce niveau est généralement réputé pour son anoxie. L'extinction en masse du Dévonien supërieur, probablement la seconde par ordre d'imporlance au cours du Pbanérozö̈que, a lieu dans les derniers $5 \mathrm{~cm}$ de l'borizon Kellwasser supérieur. Douze espèces d'Ostracodes reconnues dans la carrière Schmidt survivent à cet événement.

Mots clés: Ostracodes, Limite Frasnien/Famennien, Kellerwald, Allemagne. Extinction

\section{Version abrégée (voir p. 77)}

\section{Introduction}

The Global Stratotype Section and Point (GSSP) for the Frasnian/Famennian boundary was chosen by the Subcommission of Devonian Stratigraphy (SDS), in the upper quarry of Coumiac, in the Montagne Noire, Southern France. The decision was ratified in 1993 by the International Commission of Stratigraphy (ICS) and by the International Union of Geological Sciences (IUCS) (Klapper et al., 1994).

Vote présentée par Jean Dercourt.

Yote remise le 8 septembre 1997, acceptée le 30 septembre 1997.

E-mail casier pal@kinirsnb.be 
The Schmidt quarry in the Rhenish Slate Mountains. Germany, was an alternative candidate selected by the SDS for the choice of the Frasnian/Famennian boundary GSSP (Ibid.). But, unexpectedly for such a candidate, the study of ostracods present in the Schmidt quarry have been neglected. Only nine ostracod species were known from the late Frasnian in this section!

These nine ostracod species were reported by Walliser et al. (1989), Schindler (1990) and Groos-Uffenorde and Schindler (1990). They belong exclusively to the Myodocopida and include Ungerella sp., Entomoprimitia (E.) kayseri (Waldschmidt, 1885), Entomoprimitia (E.) splendens (Waldschmidt, 1885), Entomoprimitia sartenaeri Casier, 1977 [- Entomoprimitia variostriata (Clarke, 1884) in Walliser et al. (1989)], Entomoprimitia (E.) nitida (Ro emer, 1850), Richterina (V.) zimmermanni (Volk, 1939), Richterina (R.) sp., Cypridina sp., and maybe Entomoprimitia (E.) inconstans Müller-Steffen, 1964.

On the other hand, the study based on ostracods from southern Belgium, southern France, Nevada (USA) and Hunan (China) has provided valuable information about the Late Devonian mass extinction, one of the five greatest during the Phanerozoic (Casier et al., 1996).

For these two reasons, and also because the choice of the Upper Coumiac quarry as GSSP is already under debate (Ziegler and Sandberg, 1996), we have started the study of the ostracod fauna from the Frasnian/Famennian transition in the Schmidt quarry. Numerous benthonic ostracods species unknown until now in this section have been discovered during this study and our first results are presented helow

\section{The Schmidt quarry}

The Schmidt quarry is located $750 \mathrm{~m}$ NNE of the village of Braunau (Lat: $9^{\circ} 10^{\prime} \mathrm{E}$; Long: $51^{\circ} 6^{\prime} \mathrm{N}$ ) near Bad Wildungen in the Kellerwald, Germany (figure 1). This small abandoned quarry, with the status of a protected geological reserve, was studied among others by Ziegler (1971), Lottmann et al. (1986), Sandberg et al. (1988), Walliser et al. (1989), Schindler $(1990,1993)$ and Feist and Schindler (1994). Geochemical studies concerning this outcrop are due to Buggisch (1972) and McGhee et al. (1986).

During the Frasnian/Famennian transition, the Schmidt quarry was located in an area of hemipelagic sedimentation deposited on a submarine rise within a basin (Sandberg et al., 1988). The section is very condensed and exposes a light grey limestone succession interrupted by two horizons of black or dark-grey interstratified shales and limestones (figure 2). These two $\mathrm{C}_{\text {org }}$-rich horizons are called Lower and Upper Kellwasser from the Kellwasser Valley in the Harz Mountains where they were first recognized last century by Roemer (1850). The Lower and Upper Kellwasser horizons are $270 \mathrm{~cm}$ apart in the Schmidt quarry.

\section{Ostracod fauna and surviving species}

Thirty-nine samples were collected from the uppermost part of the Early rhenana conodont Zone (base of the Lower Kellwasser horizon) to the Middle triangularis conodont Zone in the Schmidt quarry (figure 2). Using the hot acetolyse method (Lethiers and Crasquin-Soleau, 1988), 1773 ostracods and fragments of ostracods were extracted from the top of the Frasnian (1490) and from the base of the Famennian (283). Only three samples failed to produce ostracods: DVG25 in the Lower Kellwasser horizon, DVG37 in the base of the Late rhenana conodont Zone and DVG66 at the top of the Upper Kellwasser horizon.

Compared to other sections exposing the Frasnian/ Famennian transition and especially to the Coumiac GSSP, benthonic ostracods are scarce in the Schmidt quarry. This is also the case for all other groups of invertebrates and it was principally for this reason that the candidature of the Schmidt quarry for CSSP was rejected by the Subcommission of Devonian Stratigraphy (Klapper et al., 1994).

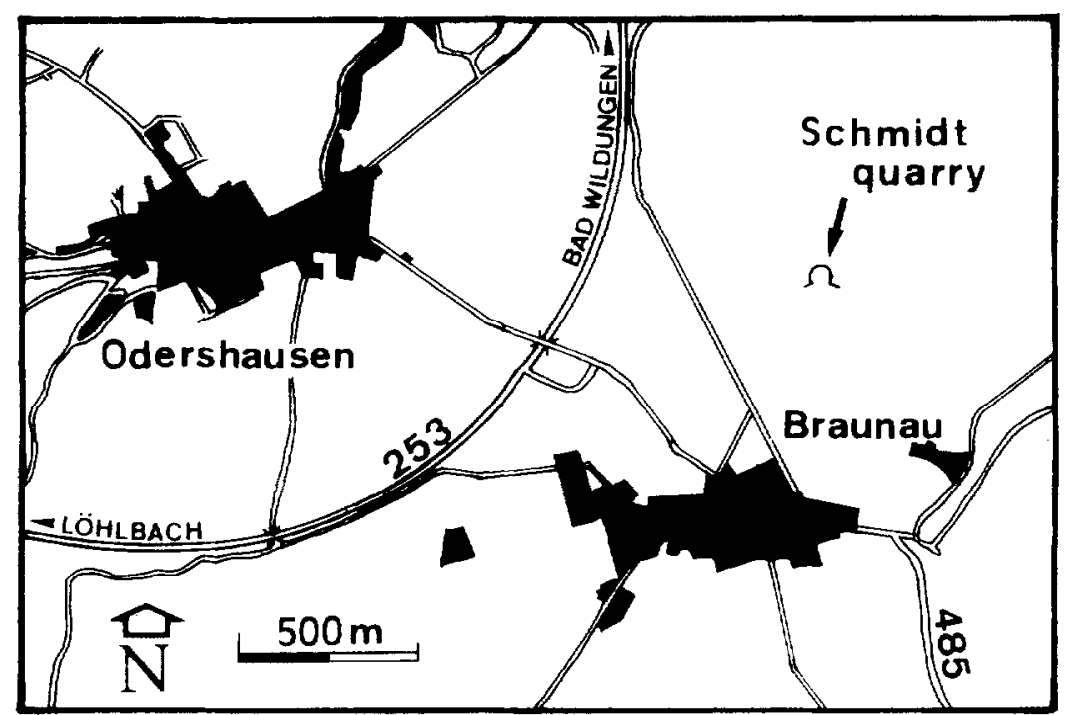

Figure 1. Locality map of the Schmidt Quarry.

Localisation de la carrière Schmidt. 


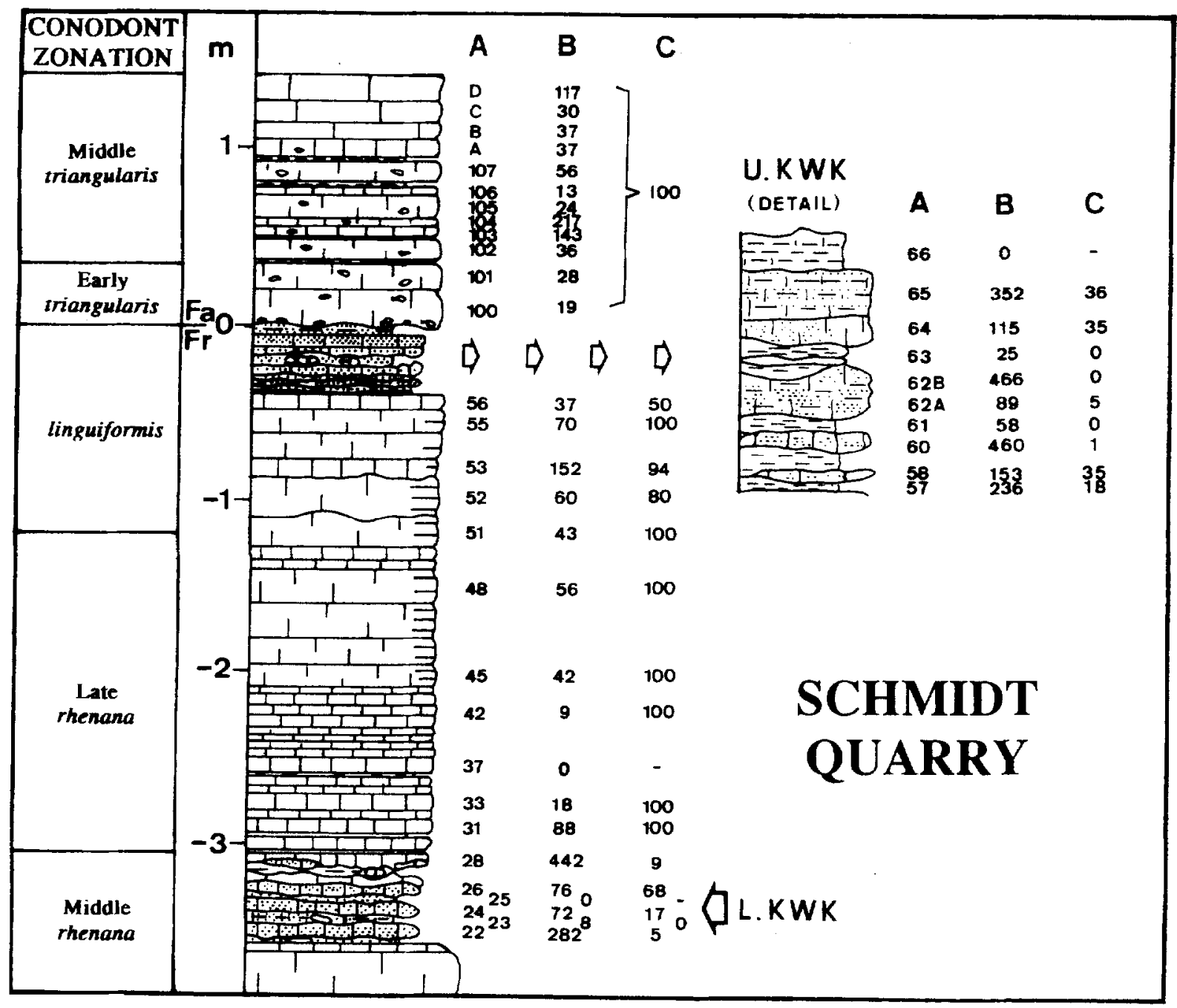

Figure 2. Lithological column of the Late Frasnian and Early Famennian in the Schmidt quarry (Schindler, 1990). Column A: position of ostracod samples; column B: number of ostracods per $100 \mathrm{~g}$ of sample; column C: percentage of ostracods belonging to the Eifelian ecotype. L.KWK: lower Kellwasser horizon. U.KWK: upper Kellwasser horizon.

Colonne lithologique du sommet du Frasnien et de la base du Famennien dans la carrière Schmidt (d'après Schindler. 1990). Colonne A : position des échantillons récoltés pour l'étude des Ostracodes ; colonne B : nombre d'Ostracodes pour $100 \mathrm{~g}$ d'échantillon ; colonne $C$ : pourcentage d'Ostracodes appartenant à l'écotype de l'Eifel. L.KWK : horizon Kellwasser inférieur ; U.KWK : horizon Kellwasser supérieur.

Sixty-eight ostracod species (tables I and II, figures 3 and 4) were recognized in the Schmidt quarry. Among the 53 species occurring in the Frasnian, seven survived in the ramennian. As five other species present in the Schmidt quarry are known from the Frasnian or the Famennian of other sections in southern Belgium, southern France or Nevada, a total of 12 species survived the Late Devonian mass extinction in the Schmidt quarry.

The rate of extinction across the Frasnian/Famennian boundary in the Schmidt quarry (about $75 \%$ ) is similar to the one reported from Coumiac, on the southern margin of the Palaeotethys (Lethiers and Casier, 1996), and from Devils Gate, on the eastern margin of the Eopacificus (Casier and Lethiers, 1998). This confirms that the Late Devonian mass extinction is a global catastrophic event as suggested earlier by McLaren (1970), Sandberg et al.
(1988) and McLaren and Goodfellow (1990). In fact, the Late Devonian mass extinction is probably the second in order of magnitude during the Phanerozoic.

The disappearance of all Frasnian species of Entomozoacea in the upper part of the Upper Kellwasser horizon is particularly spectacular at Steinbruch Schmidt but was already suspected by Groos-Uffenorde and Schindler (1990).

\section{Paleoecologic assemblages}

Ostracods close to the Frasnian/Famennian boundary in the Schmidt quarry belong to the Eifelian ecotype of Becker (Bandel and Becker, 1975) and to the Myodocopid 
Table I. Late Frasnian ostracods from the Schmidt quarry. In bold: ostracod species surviving the FF event in the Schmidt quarry or in other sections.

Ostracodes de la partie supérieure du Frasnien de la carrière Schmidt. En gras: espèces survivantes à l'événement F/F dans la carrière Schmidt ou dans d'autres coupes géologiques.

\begin{abstract}
Ampuloides sp. B; Healdianella sp. indet.; Richterina (V.) zimmermanni (VOLK, 1939); Entomoprimitia (E.) sartenaeri CASIER, 1977; Bairdiacypris? sp. indet.; Cypridinacea? indet.; Entomozoe (N.) tenera (GÜRICH, 1896); Ungerella nov. sp. A, aff. sigmoidale (MÜLLERSTEFFEN, 1964); Famenella postkairovaensis LETHIERS \& CASIER, 1996; Bairdiacypris? sp. B LETHIERS \& CASIER, 1996; Kloedenellidae sp. indet.; Bairdia sp. indet.; Micronewsomites natus (ROZHDESTVENSKAJA, 1972); Bairdia (B.) cf. finifracta BLUMENSTENGEL, 1970; Bairdia (B.) trigona BLUMENSTENGEL, 1965; Acratia cf. supina POLENOVA, 1953; Amphissites imbecillus LETHIERS \& CASIER, 1996; Bairdiacypris sp. A sensu LETHIERS CASIER, 1996; Bairdia (O.) nov. sp. C, aff. philippovae EGOROV, 1953; Podocopida indet.; Polenovia pseudomagna (S I EWART \& HENDRIX, 1945); Acratia gr. rostratiformis SCHEVTSOV, 1964; Coelonella? sp. indet.; Praepilatina? sp. indet.; Healdianella sp. A; Bairdia nov. sp. A, aff. galinaeformis LETHIERS, 1981 ; Acratia cf. tichonovitchi EGOROV, 1953; Bairdia nov. sp. B, aff. subeleziana POLENOVA, 1953; Acratia nov. sp. B, aff. paraschelonica LETHIERS, 1974, sensu CASIER \& LETHIERS, 1998; Pachydomellidae indet.; Acratia n. sp. A?; Healdianella cf. alba LETHIERS, 1981; Famenella cf. bisangulata LETHIERS, 1981; Ampuloides n. sp. A, aff. parvus BLUMENSTENGEL, 1971, sensu LETHIERS \& CASIER, 1996; Bairdiacypris cf. irregularis (POLENOVA, 1953); Decoranewsomites multicavus (ROZHDESTVENSKAJA, 1972); Bairdia sp. C, aff. proximischimensis CASIER \& LETHIERS, 1998; Entomoprimitia (E.) nitida (ROEMER, 1850); Schneideria? groosae BECKER, 1971; Bairdia (R.) cf. phillipovae EGOROV, 1953 sensu CASIER \& LETHIERS, 1997; Samarella sp. indet.; Bairdia cf. referta ROZHDESTVENSKAJA, 1972; Ungerella cf. calcarata (RICHTER, 1856); Entomoprimitia (E.) splendens (WALDSCHMIDT, 1885); Entomoprimitia (E.) inconstans MÜLLER-STEFFEN, 1964; Entomozoe (N.) cf. tenera (GÜRICH, 1896); Bairdia eifliensis KUMMEROW, 1953, sensu BLUMENSTENGEL, 1970; Bairdia cf. fabaeformis POLENOVA, 1953, sensu LETHIERS \& CASIER, 1996; Bairdiacypris anteroangulosa CASIER \& LETHIERS, 1997; Entomoprimitia (E.) kaysen (WALDSCHMIDT, 1885); Pribylitidae? sp. indet.; Bairdiocypris n. sp. A; Bairdiocypris? sp. indet; Bairdiohealdites $\mathrm{sp}$ A, aff. gregalis ROZHDESTVENSKAJA, 1972; Knoxiella? cf. rauseri (TSCHIGOVA, 1977); Knoxiella cf. domanica ROZHDESTVENSKAJA, 1972; Aparchitidae sp. indet.; Frolovia sp. A, aff. sohni SHISHKINSKAIA, 1964; Entomozoacea sp. indet.
\end{abstract}

Table II. Early Famennian ostracods from the Schmidt quarry. In bold: ostracod species surviving the FF event in the Schmidt quarry or in other sections.

$x+4)$

Ostracodes de la partie inférieure du Famennien de la carrière Schmidt. En gras : espèces survivantes à l'événement F/F dans la carrière Schmidt ou dans d'autres coupes géologiques.

ramenella postkairovaensis LETHIERS \& CASIER, 1996; Bairdia sp. indet; Micronewsomites natus (ROZHDESTVENSKAJA, 1972); Amphissites imbecillus LETHIERS \& CASIER, 1996; Bairdia nov. sp. A, aff. galinaeformis LETHIERS, 1981; Acratia cf. tichonovitchi EGOROV, 1953; Acratia n. sp. A; Bairdia sp. C, aff. proximischimensis CASIER \& LETHIERS, 1998; Bairdia cf. fabaeformis POLENOVA, 1953, sensu LETHIERS \& CASIER, 1996; Cytherellina sp. indet.; Ampulvides sp. indet,; Acratia cf. gassanovea EGOROV, 1953; Micronewsomites sp. indet. I; Praebythoceratina sp. indet.; Acratia n. sp. B; Aparchites? sp. indet.; Famenella n. sp. A, aff. perspiqua ROZHDESTVENSKAJA, 1972; Acratia sp. D, aff. rostrata ZANINA, 1956, sensu BECKER \& BLESS, 1974, pp; Aparchites sp. A; Aparchites sp. B; Bairdiocypris aff. rudolphi (KUMMEROW, 1939) sensu BECKER \& BLESS, 1974, pp; Acratia cf. sp. E LETHIERS, 1981; Micronewsomites sp. indet. II; Coeloenella sp. indet.

ecotype. Ostracods belonging to the Eifelian ecotype are generally characterized by thick-shelled well calcified carapaces, whereas ostracods belonging to the Myodocopid ecotype are generally characterized by a fingerprint ornamentation.

1. The Eifelian ecotype characterizes lagoonal to shallow marine environments (nearshore to offshore) in the
Paleotethys. In the Schmidt quarry, ostracods belonging to this ecotype are generally small (the majority are found in the $100-250 \mu \mathrm{m}$ sieving fraction!), and they are dominated by Podocopids. These deposit-feeder ostracods are indicative of well oxygenated water conditions. Hundred per cent of the ostracod fauna in the Famennian part of the section and quasi $100 \%$ of the ostracod fauna in the light 


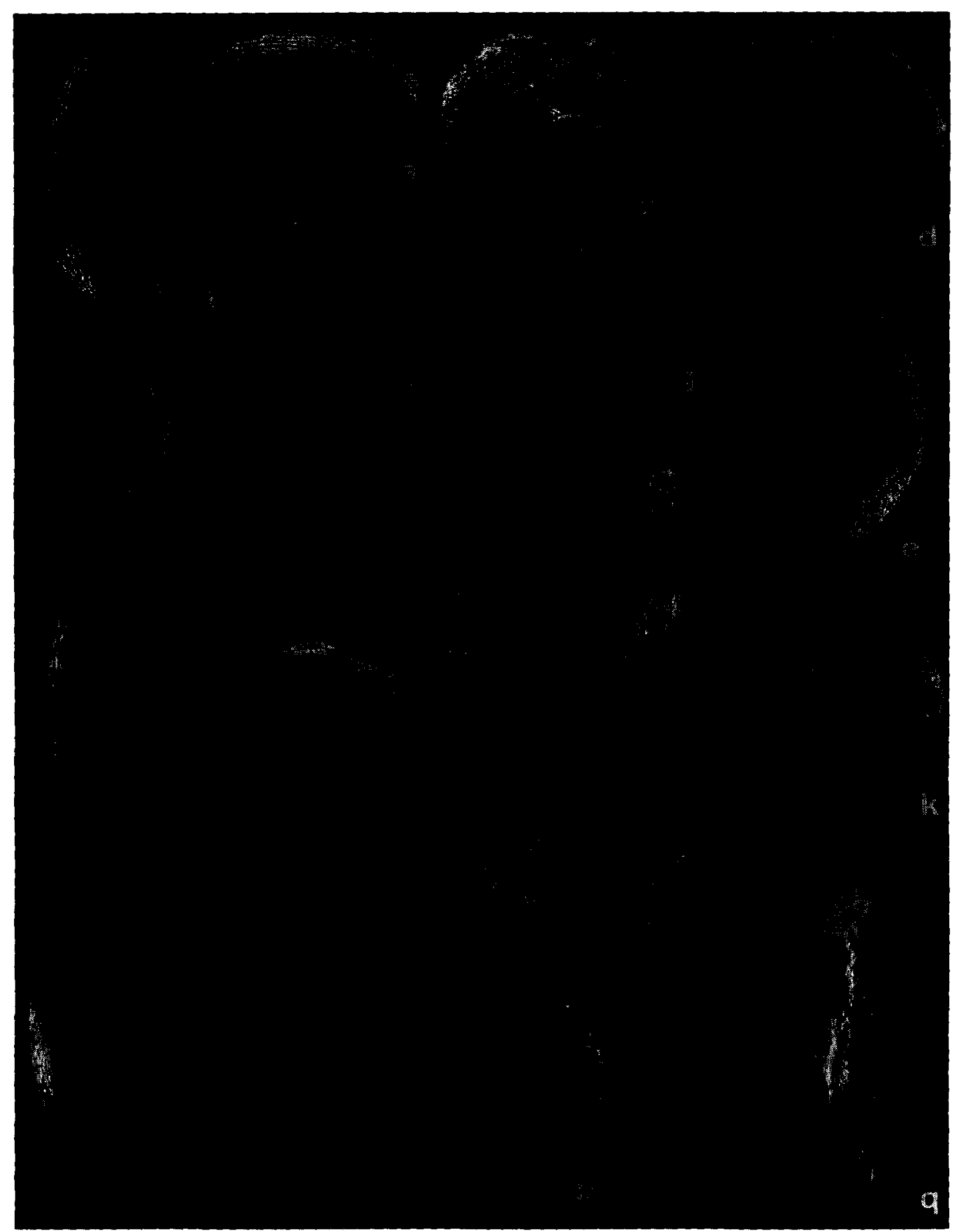

Figure 3. Ostracods belonging to the Myodocopid ecotype. IRScNB $n^{\circ}=$ coll. number of the Dep. Pal., Belg. Roy. Inst. Nat. Sci. A, C, D, F, C, I, $K, M, O, P=$ lateral views; $B, E, H, J, L, N, Q=$ dorsal views.

Ostracodes appartenant à l'écotype à Myodocopida. IRSCNB n $n^{\circ}=$ numéro de collection du Dép. Pal. Inst. roy. Sci. nat. Belgique. A, C, D, F, G, I, $K, M, O, P=$ vues latérales $; B, E, H, L, L, N, Q=$ vues dorsales.

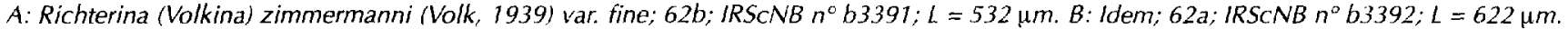
C: Entomoprimitia (Entomoprimitia) sartenaeri (Casier, 1977); 57; $I R S_{C N B}{ }^{\circ}$ b3393, $L=696 \mu \mathrm{m}$. D. E: Entomoprimitia (Entomoprimitia) splendens (Waldschmidt, 1885); 57; IRSCNB $n^{\circ}$ b3394; $L=1228 \mu \mathrm{m}$. F: Polenovia pseudomagna (Stewart and Hendrix, 1945); 62a; IRSCNB $n^{\circ}$ b3395;

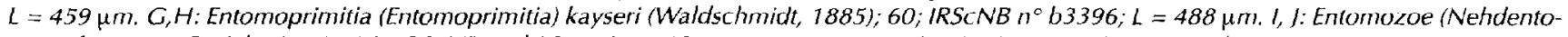
mis) cf. tenera (Gürich, 1896); 58; IRSCNB $n^{\circ}$ b3397; $L=903 \mu \mathrm{m} . K$, L: Entomoprimitia (Entomoprimitia) nitida (Roemer, 1850); 60; IRSCNB $n^{\circ}$ b3398; $L=947 \mu \mathrm{m} . \mathrm{M}, \mathrm{N}$ : Entomoprimitia (Entomoprimitia) inconstans Müller-Steffen, 1964; 60; IRSCNB n ${ }^{\circ}$ b3399; $1302 \mu \mathrm{m}$. O: Ungerella nov. sp. A, aff. sigmoidale (Müller-Steffen, 1964); 62a; IRSCNB n' b3400;L =651 um. P. Q: Entomozoe (Nehdentomis) tenera (Gürich, 1896); 57; IRSCNB $n^{\circ} b 3401 ; L=1214 \mu \mathrm{m}$.

C. R. Acad. Sci. Paris, Sciences de la terre et des planètes / Earth \& Planetany Sciences 


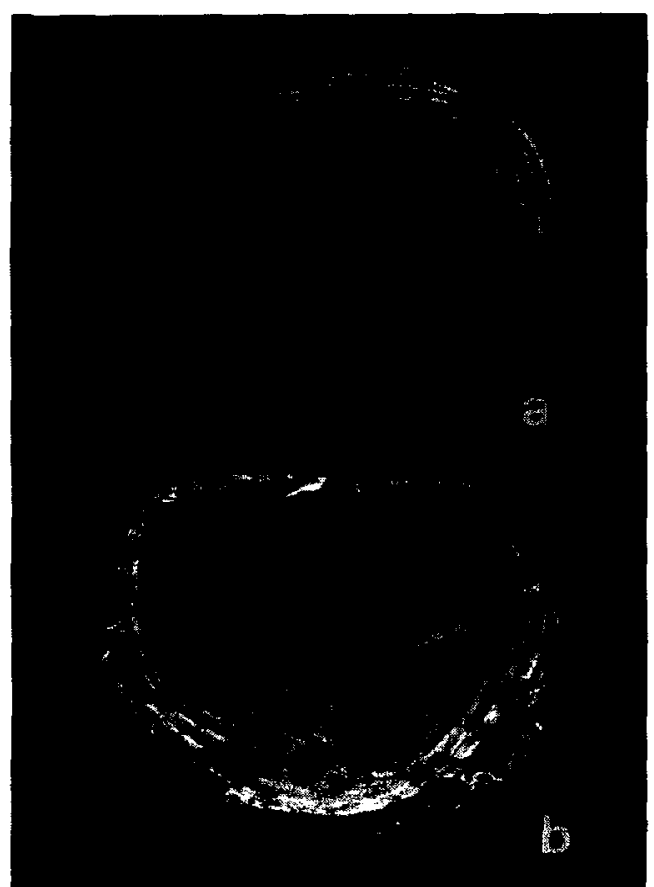

Figure 4. Entomoprimitia (Entomoprimitia) kayseri (Waldschmidt, 1885); 60, IRScNB $n^{\circ}$ b3402; $L=962 \mu \mathrm{m}$. External (A) and internal (B) views of an exceptionally well preserved valve. This heavy calcified and thick shelled (thickness $=44 \mu \mathrm{m}$ ) valve shows the ornamentation on both sides.

Vue externe (A) et interne (B) d'une valve exceptionnellement bien conservée. Elle est épaisse (ép. $=44 \mu \mathrm{m}$ ), fortement calcifiée et montre lornementation sur ses deux faces.

grey Frasnian limestone succession between the two Kellwasser horizons beiong to this assemblage of the Eifelian ecotype. In the Upper Kellwasser horizon, six samples out of ten contain ostracods of this ecotype.

2. The Myodocopid ecotype ( $=$ Entomozoacea ecotype of Becker, ibid.) is characterized by larger ostracods belonging to the Entomozoacea and the Cypridinacea (figures 3 and 4). The mode of life of these ostracods, nektoplanktonic or nekto-benthonic, is controverted (GroosUffenorde and Schindler, 1990; Casier, 1987, 1992; Lethiers and Casier, 1995) but there is an agreement to estimate that when they are present alone, they are indicative of poorly oxygenated water conditions. These ostracods are very abundant in the two Kellwasser horizons and all the ostracods from samples StSch 23, 61, 62 b and 63 belong to the Myodocopid ecotype. In the light grey limestone succession between the two Kellwasser horizons, they are abundant in the sample StSch56, exactly below the Upper Kellwasser horizon, and they are repre sented by rare specimens in samples StSch 52 and 53.

\section{Oxygenation and eustatic variation}

For Buggisch (1972), Groos-Uffenorde and Schindler (1990) and others, the Upper Kellwasser horizon was deposited during a period of basin stagnation and anoxic bottom conditions proved by the absence of benthic life. Our study demonstrates on the contrary that the oxygen content of the bottom waters during the deposition of the Upper Kellwasser horizon was very variable. Sometimes the bottom waters were sufficiently oxygenated and ostracods of the Eifelian and Myodocopid ecotypes occur together (samples StSch57, 58, 64, 65), sometimes the bottom waters were deficient in oxygen and the Myodocopid ecotype is alone represented (samples StSch61, $62 \mathrm{~b}$ and 63 ) but only in the top of the Upper Kellwasser horizon (sample Stch66) were the bottom waters anoxic and ostracods were not able to survive. The most remarkable change for conodonts also occurs in these $5 \mathrm{~cm}$-thick dark carbonaceous shales (Sandberg et al., 1988). So, there is no doubt that this last bed corresponds to the acme of the Late Devonian mass extinction.

The ostracod assemblage belonging to the Eifelian ecotype present in the Upper Kellwasser horizon is similar to the one reported from the underlying light grey limestone succession. Thus no important modification of the sea level occurred at this transition. The study of the Coumiac GSSP in the Montagne Noire, had already demonstrated that eustatic fluctuations are slightly reflected in hemipelagic facies (Lethiers and Feist, 1991); on the con trary, several Belgian sections where the study of ostracods has proved the existence of a drastic sea level fall close to the Frasnian/Famennian boundary (Casier and Devleeschouwer, 1995; Casier et al., 1997).

The recovery by ostracods in the Schmidt quarry probably began owing to species sheltered in very shallow environments as it is supposed for the Coumiac GSSP in the Montagne Noire (Lethiers and Casier, 1996) and for the Devils Gate Pass section, Nevada (Casier and Lethiers, 1998).

\section{Conclusions}

Numerous benthonic ostracod species have been discovered in the Schmidt quarry and the rate of extinction close to the Frasnian/Famennian boundary in this section (about $75 \%$ ) is high and similar to the rate observed in other sections worldwide. This confirms that the Late Devonian mass cxtinction is a global catastrophic event in lower latitudes.

The study of astracods from the Schmidt quarry proves that the oxygenation was extremely variable during the deposition of the Upper Kellwasserkalk. The last $5 \mathrm{~cm}$ of this horizon alone were deposited under anoxic conditions. The anoxy is the essential factor of extinction in this hemipelagic environment. 


\section{VERSION ABRÉGÉE}

\section{Introduction}

La coupe de la carrière Schmidt, près de Bad Wildungen, dans le Kellerwald, en Allemagne (figure 1), est considérée comme l'une des meilleures coupes de référence pour la limite des étages Frasnien et Famennien (Klapper et al., 1994). La sédimentation, très condensée et de type hémipélagique, s'y présente sous forme d'unc succession de calcaires grisâtres, interrompue par deux horizons de calcaires et shales gris foncé ou noirs Ces deux horizons, plus riches en matière organique et distants de $270 \mathrm{~cm}$, sont communément appelés Kellwasser inférieur et supérieur (figure 2).

\section{Les Ostracodes et leur survie}

Trente-six échantillons ont été récoltés depuis la partie supérieure de la Zone inférieure à rhenana (base du Kellwasser Inférieur) jusqu'à la Zone moyenne à triangularis des Conodontes (figure 2) et 1773 carapaces, valves et fragments d'Ostracodes ont été extraits, 1490 dans le sommet du Frasnien et 283 dans la base du Famennien.

Soixante-huit espèces d'Ostracodes (tableau I et II, figures 3 et 4) sont rcconnucs dans la carric̀re Schmidt. Cinquante-trois sont présentes dans le Frasnien et sept survivent dans le Famennien. Comme cinq autres espèces présentes dans la carrière Schmidt sont connues du Frasnien ou du Famennien dans d'autres coupes étudiées en Belgique, dans le sud de la France ou au Nevada, 12 espèces survivantes au total sont donc recensées dans la coupe de la carrière Schmidt.

Le pourcentage d'extinction au niveau de la limite Frasnien/Famennien dans la carrière Schmidt (environ $75 \%$ ) est donc voisin de celui observé à Coumiac, sur la marge méridionale de la Paléotéthys (Lethiers et Casier, 1996), et à Devils Gatc, sur la marge orientale de l'Eopacificus (Casicr et Lethiers, 1998). Ces résultats suggèrent que l'extinction en masse du Dévonien supérieur est hien un événement catastrnphique global, comme l'avaient supposé McLaren (1970), Sandberg et al. (1988) et Mc Laren et Goodfellow (1990). En fait, l'extinction du Dévonien pourrait être la seconde par ordre d'importance au cours du Phanérozoïque.

\section{Ies associations d'Ostracodes}

Les Ostracodes de la carrière Schmidı appartiennent à deux écotypes:

- l'écotype de l'Eifel sensu Becker ( in Bandel et Becker, 1975), caractérisé par une association d'Ostracodes benthiques à carapace épaisse, où la dominance de petits Podocopida témoigne d'une bonne oxygénation générale du fond; il est

\section{REFERENCES}

Bandel K. and Becker G. 1975. Ostracoden aus paläozoischen pelagischen Kalken der Karnischen Alpen (Silurium bis Unterkarbon), Senckenberglana leth., 56, 1, 18-3

Buggisch W. 1972. Zur Geologie und Geochemie der Kell- présent presque dans tous les niveaux, de part et d'autre de la limite entre les étages Frasnien et Famennien (figure 2);

- l'écotype à Myodocopida (= écotype à Entomozoacea de Becker, ibid.), caractérisé par des Ostracodes nectoplanctoniques ou necto-benthiques appartenant aux Entomozoacea et aux Cypridinacea, et qui se rencontre presque exclusivement dans les deux horizons Kellwasser du Frasnien (figures 3 et 4 ).

\section{L'oxygénation et l'eustatisme}

Pour Buggisch (1972), Groos-Uffenorde et Schindler (1994) et de nombreux autres chercheurs, l'horizon Kellwasser supérieur s'est déposé au cours d'une stagnation des eaux marines, responsable de conditions anoxiques, comme l'attesterait l'absence de benthos. Notre étude montre, au contraire, que les conditions d'oxygénation du fond pendant le dépôt de l'horizon Kellwasser supérieur étaient très variables : par moments, des eaux du fond, suffisamment oxygénées, permettaient la coexistence d'Ostracodes appartenant aux écotypes de l'Eifel et à Myodocopida (échantillons StS57, 58, 64, 65) ; par moment, ces conditions d'oxygénation devenaient très faibles et seuls les Ostracodes de l'écotype à Myodocopida subsistaient (échantillons StSch61, 62b et 63). En fait, seuls les cinq derniers centimètres de l'horizon Kellwasser supérieur sont anoxiques, car aucun Ostracode ne survit dans ce milieu. Le changement le plus spectaculaire chez les Conodontes (Sandberg et al., 1988) prend également place dans ce niveau, où se situe donc la phase paroxysmale de lextinction en masse du Dévonien supérieur.

L'assemblage d'Ostracodes, appartenant à l'écotype de l'Eifel. présent dans l'horizon Kellwasser supérieur, est similaire à celui observé dans les calcaires gris clair sous-jacents. Il n'y a donc pas de modification significative du niveau marin à ce passage. Contrairement à ce que l'on observe dans les milieux moins profonds de la région type des étages Frasnien et Famennien, où l'étude des Ostracodes a permis de mettre en évidence une forte régression culminant au niveau de la limitc de ces étages (Casier et Devleeschouwer, 1995), l'étude des Ostracodes du stratotype de la limite à Coumiac, en Montagne Noire (France), avait déjà permis de clémontrer que les modifications eustatiques sont peu répercutées dans les faciès hémipélagiques (Lethiers et Yeist, 1991).

Le renouvellement faunique des Ostracodes dans la carrière Schmidt commence probablement à partir d'espèces réfugiées en milieu peu profond, comme c'est vraisemblablement le cas à Coumiac, en Montagne noire (Lethiers et Casier, 1996), et dans la coupe de Devils Gate, au Nevada (Casier et Lethiers, 1998). 
Casier J.-G. 1992. Description el étude des Ostracodes de deux tranchées traversant la limite historique Frasnien-Famennien dans la localifé-type, Bull. Inst. roy Sci. nat. Belgique, Sci. de la Terre, 62. 109-119

Casier J.-G. and Devleeschouwer X. 1995. Arguments (Ostracodes) pour une régression culminant d̀ proximité de la limite Frasnien - Famennien, à Sinsin. (Bord sud du Bassin de Dinant. Belgique), Bull. Inst. roy. Sci. nat. Belgique, Sci. de la Terre, 65 , $57-68$

Casier J.-G. and Lethiers F. 1998. Les Ostracodes survivants à l'extinction du Dévonien Supérieur dans la coupe du col de Devils Gate au Novada, U.S.A., Geobios (sous presse)

Casier J.-G., Lethiers F. and Claeys P. 1996. Ostracod evidence for an abrupt mass extinction at the Frasnian/Famennian boundary (Devils Gate, Nevada, USA), C. R. Acad Sci., Paris, 322, Series lia, $415-422$

Casier J.-G., Lethiers F. and Hou H.F. 1997. Ostracods from the Frasnian/Famennian transition beds in the Lijiaping section (Hunan, Southern China), C. R. Acad. Sci. Paris, 325, série lla, 433-438

Feist R, and Schindler E. 1994. Trilobites during the Frasnian Kellwasser Crisis in European Late Devonian cephalopod limesłones, Cour. Forsch.-Inst. Senckenberg. 169, 195-223

Groos-Uffenorde H. and Schindier E. 1990. The effect of giobal events on entomozoacean Ostracoda. In: Whatley R. and Maybury C. (eds). Ostracoda and Global Events, British Micropal. Soc. Publ. Ser. Chapman and Hall, 101-112

Klapper G., Feist R., Becker R. and House M. 1994. Definition of the Frasnian/Famennian stage boundary. Episodes, 16, 4, 433-441

Lethiers F. and Crasquin-Soleau S. 1988. Comment extraire les microfossiles à tests calcitiques des roches calcaires dures, Rev. Micropal. 31, 1, 56-61

Lethiers F. and Feist R. 1991. La crise des ostracodes benthiques au passage Frasnien-Famennien de Coumiac (Montagne Noire. France mëridionale), C. R. Acad. Sc. Paris, 312, Series II, 10571063

Lethiers F. and Casier J.-G. 1995. Les Ostracodes du Frasnien terminal ("Kellwasser " supérleur) de Coumiac (Montagne Noire. France), Rev. Micropal. 38, 7, 63-77
Lethiers F and Casier J.-G. 1996. Les Ostracodes survivants ò l'événement $\mathrm{F} / \mathrm{F}$ dans le limitotype de Coumiac (Montagne Noire. France), Ann. Soc. gëol. Belgique, 117 (1994), 1، 137-153

Lottmann J., Sandberg $C$., Schindler $E$., Wailiser $O$ and Ziegler $W$. 1986. Devonian events at the Ense area (excursion to the Rheinisches Schiefergebirge). Lecture Notes in Earth Sci. 8. SpringerVerlag, Berlin. Heidelberg, 17-21

McGhee G., Orth C., Quintana L., Gilmore J. and Oisen E. 1986. Late Devonian 'Kellwasser [vent' mass extinction horizon in Germany: no geochemical evidence for a large-body impact, Geology, 14, 776-779

MCLaren D. 1970. Time, life and boundaries, J. of Pal. 44, 801-815 McLaren D. and Goodfellow W. 1990. Geological and biological consequences of giant impact, Annual. Rev. Earth Planet. Sci. $18,123-171$

Roemer F. 1850. Beitrage zur Kenntnis des nordwestlichen Harzegebirges, Palaeontographica, 3,67 p.

Sandberg C., Ziegler W., Dreesen R. and Butler J. 1988. Late Frasnian mass extinction: conodont event stratigraphy, global changes, and possible cause, Cour. Forsch.-Inst. Senckenberg. $102,267-297$

Schindler E. 1990. Die Kellwasser-Krise (hohe Frasne-Stufe, OberDevon), Göttinger Arb. Geol. Paläontol., 46, 175 p.

Schindler E. 1993. Event-stratigraphic markers within the Kellwasser crisis near the Frasnian/Famennian boundary (Upper Devonian) in Germany, Palaeogeogr. Palaeoclimatol. Palaeoecol. , i04, 115-125

Walliser O. Groos-Uffenorde H. Schindler E. and Ziegler W. 1989. On the Upper Kellwasser Horizon (Boundary Frasnian/ Famennian), Cour. Forsch.-Inst. Senckenberg, 110, 247-256

Liegler W. 1971. A field trip guidebook: post-symposium excursion, Sept. 15-18. 1971 to Rhenish Slate Mountains and Harz Mountains: Marburg, Philipps University, Symposium on Conodont Taxonomy. $47 \mathrm{p}$

Ziegler $W$. and Sandberg C. 1996. Reflexions on Frasnian and Famennian Stage boundary decisions as a guide to future deliberations, Newsi. Stratigr. 33, 3, 157-180 